Article

\title{
Tocotrienol Affects Oxidative Stress, Cholesterol Homeostasis and the Amyloidogenic Pathway in Neuroblastoma Cells: Consequences for Alzheimer's Disease
}

\author{
Marcus O. W. Grimm 1,2,3,*,+, Liesa Regner ${ }^{1,+}{ }^{\dagger}$, Janine Mett ${ }^{1}$, Christoph P. Stahlmann ${ }^{1}$, \\ Pascal Schorr ${ }^{1,4}$, Christopher Nelke ${ }^{1}$, Olga Streidenberger ${ }^{1}$, Hannah Stoetzel ${ }^{1}$, Jakob Winkler ${ }^{1}$, \\ Shatha R. Zaidan ${ }^{1}$, Andrea Thiel ${ }^{1}$, Kristina Endres ${ }^{5}$, Heike S. Grimm ${ }^{1}$, Dietrich A. Volmer ${ }^{4}$ and \\ Tobias Hartmann 1,2,5 \\ 1 Experimental Neurology, Saarland University, Kirrberger Straße 1, 66421 Homburg/Saar, Germany; \\ liesa.regner@uks.eu (L.R.); janine.mett@uks.eu (J.M.); christoph.stahlmann@uks.eu (C.P.S.); \\ pascals91@gmail.com (P.S.); christophernelke@yahoo.de (C.N.); olga.streidenberger@uks.eu (O.S.); \\ hannah.stoetzel@uks.eu (H.S.); Jakob.winkler@hotmail.de (J.W.); shatharamadhan@yahoo.com (S.R.Z.); \\ andrea.thiel@uks.eu (A.T.); heike.grimm@uks.eu (H.S.G.); tobias.hartmann@mx.uni-saarland.de (T.H.) \\ 2 Neurodegeneration and Neurobiology, Saarland University, Kirrberger Straße 1, \\ 66421 Homburg/Saar, Germany \\ 3 Deutsches Institut für DemenzPrävention (DIDP), Saarland University, Kirrberger Straße 1, \\ 66421 Homburg/Saar, Germany \\ 4 Institute of Bioanalytical Chemistry, Saarland University, 66123 Saarbrücken, Germany; \\ dietrich.volmer@mx.uni-saarland.de \\ 5 Department of Psychiatry and Psychotherapy, Clinical Research Group, University Medical Centre Johannes \\ Gutenberg-University Mainz, Untere Zahlbacher Straße 8, 55131 Mainz, Germany; \\ Kristina.Endres@unimedizin-mainz.de \\ * Correspondence: marcus.grimm@uks.eu; Tel.: +49-6841-1647-919; Fax: +49-6841-1647-925 \\ + These authors contributed equally to this work.
}

Academic Editors: Maria Laura Colombo, Laura Di Renzo and Rafat A. Siddiqui Received: 31 August 2016; Accepted: 21 October 2016; Published: 29 October 2016

\begin{abstract}
One of the characteristics of Alzheimer's disease (AD) is an increased amyloid load and an enhanced level of reactive oxidative species (ROS). Vitamin E has known beneficial neuroprotective effects, and previously, some studies suggested that vitamin $\mathrm{E}$ is associated with a reduced risk of AD due to its antioxidative properties. However, epidemiological studies and nutritional approaches of vitamin $\mathrm{E}$ treatment are controversial. Here, we investigate the effect of $\alpha$-tocotrienol, which belongs to the group of vitamin E, on AD-relevant processes in neuronal cell lines. In line with the literature, $\alpha$-tocotrienol reduced the ROS level in SH-SY5Y cells. In the presence of tocotrienols, cholesterol and cholesterol esters, which have been shown to be risk factors in $\mathrm{AD}$, were decreased. Besides the unambiguous positive effects of tocotrienol, amyloid- $\beta(A \beta)$ levels were increased accompanied by an increase in the activity of enzymes responsible for $A \beta$ production. Proteins and gene expression of the secretases and their components remained unchanged, whereas tocotrienol accelerates enzyme activity in cell-free assays. Besides enhanced $A \beta$ production, tocotrienols inhibited $A \beta$ degradation in neuro 2a (N2a)-cells. Our results might help to understand the controversial findings of vitamin $\mathrm{E}$ studies and demonstrate that besides the known positive neuroprotective properties, tocotrienols also have negative characteristics with respect to $\mathrm{AD}$.
\end{abstract}

Keywords: tocotrienol; vitamin E; Alzheimer's disease; amyloid- $\beta$; tocopherol; $A \beta$ degradation; $\beta$-secretase; $\gamma$-secretase 


\section{Introduction}

Alzheimer's disease (AD) is a devastating neurodegenerative disorder and the most common cause of dementia in the elderly, pathologically characterized by neuritic plaques and intracellular neurofibrillary tangles (NFTs). Neuritic plaques are composed of aggregated amyloid- $\beta$ (A $\beta$ ) peptides, generated by sequential proteolytic processing of the amyloid precursor protein (APP) by the aspartyl-proteases $\beta$ - and $\gamma$-secretase, whereas hyperphosphorylated microtubule-associated protein tau is the main component of NFTs [1-3]. Although extracellular neuritic plaques consisting of aggregated $A \beta$ peptides are the undisputable characteristic feature of $A D$, increasing evidence suggests that the oligomeric form of $A \beta$ with up to $50 A \beta$ subunits represents the most toxic species of $A \beta[4,5]$. Several mechanisms of $A \beta$ toxicity play a crucial role in $A D$, including cholinergic dysfunction, disruption of calcium homeostasis, inflammation, increased oxidative stress and mitochondrial dysfunction, finally resulting in neuronal/synaptic dysfunction and neuronal loss [6-10]. So far, increased age seems to be the most significant risk factor contributing to sporadic AD. Furthermore, carrying one or two copies of the apolipoprotein E (Apo E) $\varepsilon 4$ alleles, one of the main apolipoproteins in the brain importing cholesterol into neurons via lipoprotein receptor-related protein, is a major risk factor for late-onset sporadic AD [11]. Hypercholesterolemia has also been proposed to be a risk factor in Alzheimer's disease, especially for the amyloid pathology, which has been confirmed by several longitudinal, population-based studies, demonstrating that cholesterol is associated with AD in later lifespan [12]. Further studies support that cholesterol metabolism is linked to the susceptibility to AD. Diet-induced hypercholesterolemia in a transgenic mouse model for AD increased total A $\beta$ levels, whereas cholesterol-lowering drugs reduced $A \beta$ pathology in transgenic mice [13-15]. Rabbits fed with a cholesterol-rich diet showed a two-fold increase in $\beta$-amyloid concentration in the hippocampal formation [16]. Molecular and mechanistic evidence points towards a direct effect of cholesterol in $\mathrm{AD}$ pathogenesis by enhancing $\beta$ - and $\gamma$-secretase-mediated $\mathrm{A} \beta$ production [17-21]. Several clinical trials associated statins, inhibiting the 3-hydroxy-3-methylglutaryl-CoA reductase (HMGCR) and, thus, cholesterol de novo synthesis, with a diminished risk to AD [22-24], whereas other clinical studies showed no differences [25-27]. However, cholesterol modulation might be an effective approach for reducing the risk of developing $\mathrm{AD}$.

Molecules of the vitamin E family have been shown to exert hypocholesterolemic properties [28-32]. Vitamin E mainly consists of two families of lipophilic compounds: tocopherols and tocotrienols. Both families share a chromanol ring and an isoprenoid-derived side chain (Figure 1A). The side chain is saturated in tocopherols and unsaturated in tocotrienols. The chromanol ring of tocopherols and tocotrienols can be methylated at position $C 5$ and $C 7$ leading to $\alpha-, \beta-, \gamma$ - and $\delta$-tocopherol or tocotrienol. Vitamin $\mathrm{E}$ is an essential component of the human diet and was primarily recognized for its antioxidant activity [33]. This micronutrient has already been proposed as a preventive agent in AD as increased oxidative stress by free radicals plays a crucial role in AD pathogenesis [34-36]. Tocotrienols also show a variety of neuroprotective activity, including anti-inflammatory activity [37-41]. However, besides the undisputable protective effects of vitamin E molecules, it has recently been shown that tocopherols increase the $A \beta$ level [42]. However, so far, nothing is known about the amyloidogenic potential of tocotrienol. Therefore, we analyzed in the present study the effect of tocotrienol on $A \beta$ generation and $A \beta$ degradation. 
A: structure of:Tocopherol / Tocotrienol

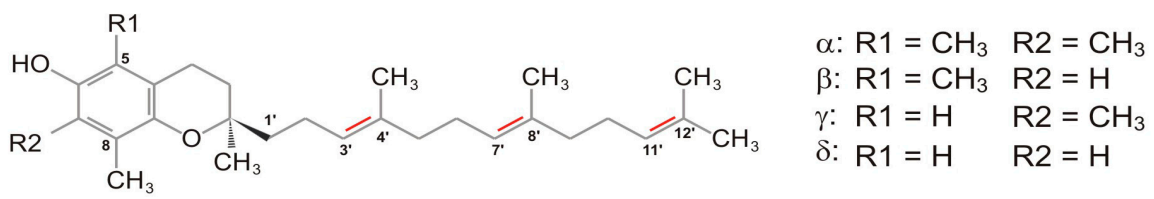

Tocotrienol: Doublebond between C3' and C4' , C7' and C8' and C11' and C12'
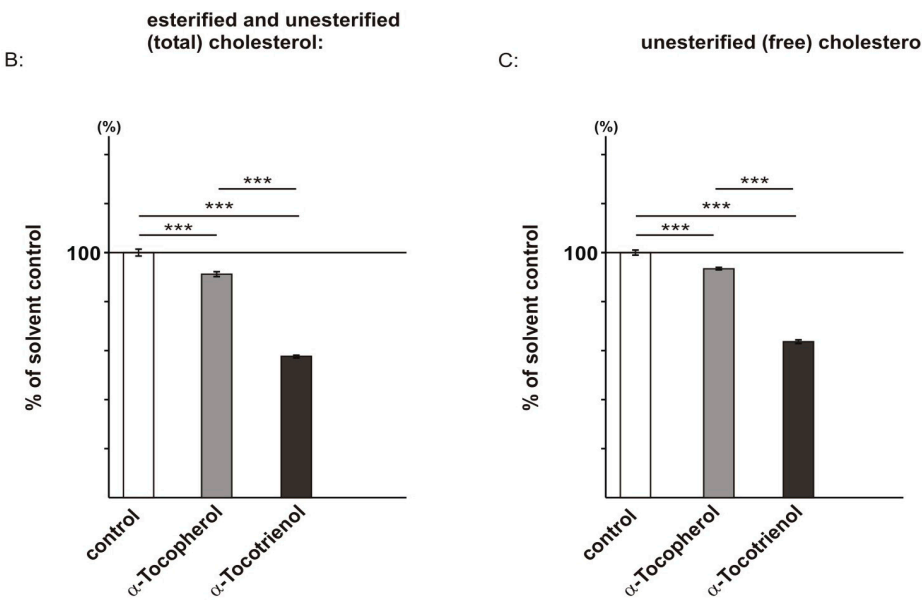

Figure 1. Effect of $\alpha$-tocopherol and $\alpha$-tocotrienol on cholesterol level. Error bars represent the standard deviation of the mean. Asterisks show the statistical significance calculated by post hoc ANOVA compared to the solvent control (*** $p \leq 0.001$ ). (A) Skeletal formulas of $\alpha$-tocopherol and $\alpha$-tocotrienol. The red lines indicate the double bonds; (B,C) effect of $\alpha$-tocopherol and $\alpha$-tocotrienol in SH-SY5Y wildtype cells on esterified and unesterified (total) cholesterol (B) ( $\alpha$-tocopherol: $91.2 \% \pm 1.0 \%$, $p \leq 0.001, n=8 ; \alpha$-tocotrienol: $57.7 \% \pm 0.6 \%, p \leq 0.001, n=8$ ) and unesterified (free) cholesterol (C) $(\alpha$-tocopherol: $93.4 \% \pm 0.5 \%, p \leq 0.001, n=8$; $\alpha$-tocotrienol: $63.7 \% \pm 0.7 \%, p \leq 0.001, n=8$ ) compared to the solvent control. One hundred percent in the control cells equates $0.0211 \mu \mathrm{g}$ total cholesterol/ $\mu \mathrm{g}$ protein $(\mathbf{B})$ and $0.0161 \mu \mathrm{g}$ free cholesterol/ $\mu \mathrm{g}$ protein $(\mathbf{C})$.

\section{Results}

\subsection{Effect of $\alpha$-Tocopherol and $\alpha$-Tocotrienol on Cholesterol Level}

As described above, the vitamin E family consists of tocopherols and tocotrienols. $\alpha$-tocopherol is the most abundant form among the tocopherols and mainly used in supplements; in accordance, $\alpha$-tocotrienol is the most common form of the tocotrienols [43]. We therefore investigated the effect of both $\alpha$-forms, which only differ in their chemical structure in the number of double bonds, on the cholesterol level.

Vitamin E compounds have been shown to exert hypocholesterolemic activity by affecting the sterol regulatory element binding protein/SREBP cleavage activating protein (SREBP/SCAP) system, one of the main systems regulating cholesterol homeostasis [28,30,44-46]. High cholesterol levels are discussed to be a risk factor for $\mathrm{AD}$ [12]. Cellular cholesterol exists in two major forms: (1) unesterified (free) cholesterol that possess a free $3-\beta-\mathrm{OH}$ at the steroid ring $\mathrm{B}$, instead of; and (2) cholesteryl esters (esterified cholesterol). Cholesterol acyltransferase (ACAT) responsible for the conversion of free cholesterol to esterified cholesterol has been shown to be affected in AD [47]. In principle, vitamin E molecules could not only influence cholesterol de novo synthesis by affecting the SREBP/SCAP system, but also alter cholesterol-esterase or cholesterol-ester synthase activity. Therefore, we determined in the present study unesterified, as well as total cholesterol levels. 
As the above-mentioned studies were performed in non-neuronal cell lines, we used human neuroblastoma SH-SY5Y wildtype (wt) cells to determine the effect of $\alpha$-tocopherol and $\alpha$-tocotrienol on non-esterified and total cellular cholesterol, including esterified cholesterol level. Cells were maintained for three days in 1\% fetal calf serum (FCS) in the presence of $10 \mu \mathrm{M} \alpha$-tocopherol or $\alpha$-tocotrienol, followed by treatment for $48 \mathrm{~h}$ in $0.1 \% \mathrm{FCS}$, to further reduce external sterol sources. Notably, we used a concentration of $10 \mu \mathrm{M}$, as it has been shown that tocopherol isomers occur in the human brain in concentrations of 0.11-17.9 $\mu \mathrm{M}$ [48]. Cholesterol levels were determined using an Amplex Red-based cholesterol assay, either in the absence of cholesterol-esterase for the determination of free cholesterol (unesterified cholesterol) or in the presence of cholesterol-esterase for the analysis of total cholesterol level (esterified and unesterified cholesterol). The $\alpha$-tocopherol-treated cells showed a slight, but significant reduction in total cholesterol to $91.2 \%$ and free cholesterol level to 93.4\% compared to solvent-treated SH-SY5Y wt cells ( $\alpha$-tocopherol: total cholesterol: $91.2 \% \pm 1.0 \%$, $p \leq 0.001$; free cholesterol: 93.4\% $\pm 0.5 \%, p \leq 0.001$ ) (Figure 1B,C). For $\alpha$-tocotrienol, we found a strong and significant reduction in total and free cholesterol level. In the presence of $\alpha$-tocotrienol, the total cholesterol level was decreased to $57.7 \%$ and the free cholesterol level to $63.7 \%$ ( $\alpha$-tocotrienol: total cholesterol: $57.7 \% \pm 0.6 \%, p \leq 0.001$; free cholesterol: $63.7 \% \pm 0.7 \%, p \leq 0.001)$. Remarkably, compared to $\alpha$-tocopherol, the reduction of total cholesterol and unesterified cholesterol level in $\alpha$-tocotrienol-treated cells is highly significant (Figure 1B,C).

\subsection{Reactive Oxidative Species Are Reduced in the Presence of $\alpha$-Tocopherol and $\alpha$-Tocotrienol}

Vitamin E is known for its antioxidant activity [33]. To analyze whether tocopherols and tocotrienols exert different effects on the production of reactive oxidative species (ROS), we incubated SH-SY5Y wt cells $24 \mathrm{~h}$ in FCS-reduced culture medium in the presence of $10 \mu \mathrm{M} \alpha$-tocopherol or $\alpha$-tocotrienol. Notably, at these experimental conditions, $\alpha$-tocopherol and $\alpha$-tocotrienol showed no significant changes in cytotoxicity compared to solvent-treated control cells (Figure S1). 2-[6-(4'-amino)phenoxy-3H-xanthen-3-on-9-yl]benzoic acid (aminophenyl fluorescein (APF)) was used to selectively detect highly reactive oxygen species (hROS), including hypochlorite (-OCl) and free hydroxyl radical (.OH) [49]. The generation of ROS was slightly, but not significantly reduced to $88.3 \%$ in the presence of $\alpha$-tocopherol (Figure 2A) compared to solvent-treated cells. A very similar, but significant reduction to $84.9 \%$ was obtained for $\alpha$-tocotrienol ( $\alpha$-tocopherol: $88.3 \% \pm 3.6 \%$, $p=0.07 ; \alpha$-tocotrienol: $84.9 \% \pm 2.6 \%, p=0.012$ ). The determination of ROS level, induced by using hydrogen peroxide $\left(\mathrm{H}_{2} \mathrm{O}_{2}\right)$, revealed a significant reduction to $91.6 \%$ for $\alpha$-tocopherol ( $\alpha$-tocopherol: $91.6 \% \pm 3.2 \% ; p=0.029$ ) (Figure 2B). The $\alpha$-tocotrienol-treated cells showed a reduction to $89.1 \%$ for $\mathrm{H}_{2} \mathrm{O}_{2}$-induced ROS level ( $\alpha$-tocotrienol: $89.1 \% \pm 2.3 \%, p=0.006$ ). Similar to the results for ROS level detected by APF, we observed no significant differences in $\mathrm{H}_{2} \mathrm{O}_{2}$-induced ROS levels between $\alpha$-tocopherol and $\alpha$-tocotrienol treatment (Figure 2A,B).

\subsection{Effect of $\alpha$-Tocotrienol on $A \beta$ Generation and $A \beta$ Degradation}

In a previous study, we have shown that tocopherols increase the $A \beta$ level [42]. The total $A \beta$ level depends on $A \beta$ generation by proteolytic processing of APP and A $\beta$ clearance by $A \beta$ degrading enzymes, like neprilysin or insulin-degrading enzyme (IDE) [50-54]. To analyze the effect of $\alpha$-tocotrienol on $A \beta$ generation, we focused on the amyloidogenic pathway involving $\beta$ - and $\gamma$-secretase cleavage of APP (Figure 3A). $\beta$-site shedding of APP by BACE1 initiates the production of $A \beta$ peptides, generating soluble sAPP $\beta$ and a membrane-tethered $C$-terminal fragment called $\beta C T F$ or C99, which is further cleaved by the $\gamma$-secretase complex to release A $\beta$ [2]. The influence of $\alpha$-tocotrienol on the total A $\beta$ level was analyzed in SH-SY5Y cells stably transfected with human APP695, an APP isoform mainly expressed in neurons [55]. The A $\beta$ level was determined by using the antibody W02, recognizing an epitope between amino acids 1-10 of the $A \beta$ peptide, thus, detecting the total $A \beta$ level $(A \beta 1-X)$ including $A \beta 1-40$ and $A \beta 1-42$. $\alpha$-tocotrienol significantly increased the total $\mathrm{A} \beta$ level to $116.7 \%(116.7 \% \pm 3.1 \%, p \leq 0.001)$ (Figure 3B). An increase in the $\mathrm{A} \beta$ level to $116.7 \%$ 
might appear rather small; however, one has to take into consideration that $\mathrm{AD}$ has a long preclinical phase and that a small increase in the $A \beta$ level can result in an earlier disease onset [56].
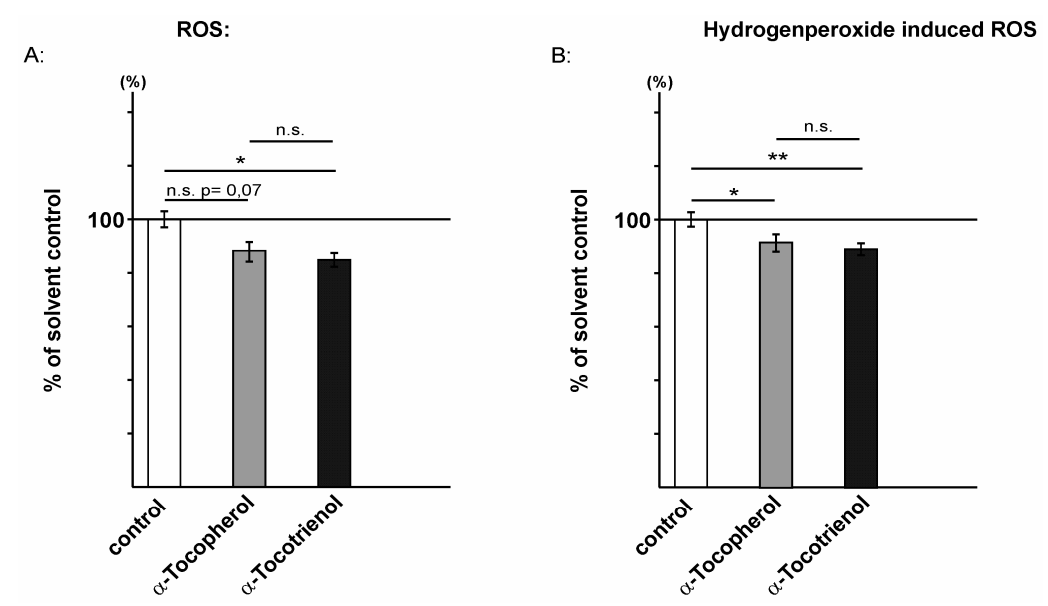

Figure 2. Effect of $\alpha$-tocopherol and $\alpha$-tocotrienol on oxidative stress. Reactive oxidative species measured with aminophenyl fluorescein (APF) (A) ( $\alpha$-tocopherol: 88.3\% $\pm 3.6 \%, p=0.07, n=16$; $\alpha$-tocotrienol: $84.9 \% \pm 2.6 \%, p=0.012, n=16)$ or induced reactive oxidative stress by hydrogen peroxide incubation (B) ( $\alpha$-tocopherol: $91.6 \% \pm 3.2 \% ; p=0.029, n=10 ; \alpha$-tocotrienol: $89.1 \% \pm 2.6 \%$, $p=0.006, n=10$ ) in the presence of $\alpha$-tocopherol and $\alpha$-tocotrienol in SH-SY5Y wildtype cells. Statistical significance as described for Figure $1{ }^{*} p \leq 0.05,{ }^{* *} p \leq 0.01$ and n.s., not significant). In (A), the oxidative stress is measured by APF detecting several reactive oxidative species with different efficiency. Therefore, an absolute value of the ROS cannot be presented. However, we estimated the concentration of ROS by using $\mathrm{NaOCl}$. The determined amount of $\mathrm{NaOCl}$ has shown the same APF-mediated fluorescence, which has been measured in the control cells. One hundred percent in the control cells equates to $2.89 \mathrm{nM} \mathrm{NaOCl}$; In (B), $100 \%$ is the equivalent of $0.95 \mu \mathrm{M} \mathrm{H}_{2} \mathrm{O}_{2}$.

To exclude unphysiologically-relevant effects by the use of APP overexpressing cells, we also incubated SH-SY5Y wildtype (wt) cells in the presence of $10 \mu \mathrm{M} \alpha$-tocotrienol or the solvent control. For SH-SY5Y wt cells, we observed an even stronger increase in the A $\beta$ level in the presence of $\alpha$-tocotrienol $(146.7 \% \pm 2.3 \%, p \leq 0.001)$ (Figure $3 C$ ). The increased effect strength might be explained by the fact that potential effects on $A \beta$ degradation are less visible in a system where de novo synthesis of $A \beta$ is as high as in APP overexpressing cells.

To analyze whether $\alpha$-tocotrienol directly affects secretase activities, we used post-nuclear membrane fractions of SH-SY5Y wt cells and measured $\beta$ - and $\gamma$-secretase activity. Therefore, purified membranes were prepared from SH-SY5Y wt cells. After preparation, these purified membranes were in vitro incubated in the presence or absence of $\alpha$-tocotrienol, and $\beta$ - and $\gamma$-secretase activity was determined. As $\alpha$-tocotrienol was added after the membranes were prepared, the observed effects on secretase activities are independent of tocotrienol-mediated changes in gene expression or cholesterol level or other mechanisms, which are dependent on intact cells. We found that $\alpha$-tocotrienol directly increased $\beta$-secretase activity to $116.3 \%$ ( $\beta$-secretase activity: $116.3 \% \pm 3.3 \%, p=0.01$ ) (Figure 3D). Western blot analysis of the SAPP $\beta$ level in the conditioned medium of tocotrienol-treated SH-SY5Y APP695 cells revealed an increased SAPP $\beta$ protein level to $136.8 \%(136.8 \% \pm 3.3 \%, p=0.004)$ (Figure S2), further underlining increased $\gamma$-secretase cleavage in the presence of tocotrienol. Similarly, we observed a direct effect of $\alpha$-tocotrienol on $\gamma$-secretase activity, which was elevated to $118.3 \%$ in the presence of $\alpha$-tocotrienol compared to solvent-treated control cells ( $\gamma$-secretase activity: $118.3 \% \pm 4.5 \%$, $p=0.02$ ) (Figure 3E). To verify the direct effect on $\gamma$-secretase activity, we investigated SH-SY5Y cells stably expressing C99. As the A $\beta$ level in C99 transfected cells is only dependent on $\gamma$-secretase cleavage, potential alterations in the A $\beta$ level are caused by changes in $\gamma$-secretase processing [57]. In line with the observed increased $\gamma$-secretase activity (Figure 3E), the $\mathrm{A} \beta$ level was elevated to 
$133.6 \%(133.6 \% \pm 2.8 \%, p \leq 0.001)$ in tocotrienol-incubated C99 transfected SH-SY5Y cells (Figure S3). The direct effect of tocotrienol on secretase activities could be substantiated by increased $\beta$ - and $\gamma$-secretase activity in living SH-SY5Y wt cells in the presence of $\alpha$-tocotrienol ( $\beta$-secretase activity: $118.3 \% \pm 4.6 \%, p=0.001 ; \gamma$-secretase activity: $132.6 \% \pm 7.3 \%, p=0.0003)$. Besides the direct effect of $\alpha$-tocotrienol on $\beta$ - and $\gamma$-secretase activity, we analyzed whether indirect tocotrienol-mediated mechanisms, like gene expression, might be involved in elevated amyloidogenic APP processing. Quantitative real-time PCR analysis revealed no changes in gene transcription of $\beta$-secretase BACE1 (Figure S4). Gene expression of the $\gamma$-secretase components presenilin 1 (PSEN1) and presenilin 2 (PSEN2), nicastrin (NCSTN), presenilin-enhancer 2 (PSENEN) and anterior-pharynx-defective 1A (APH1A) was also unchanged in the presence of $\alpha$-tocotrienol (Figure S4). Only gene transcription of the $\gamma$-secretase component APH1B was slightly, but significantly reduced to $85.2 \%(85.2 \% \pm 3.4 \%$, $p \leq 0.001)$. In accordance with the unchanged gene transcription of BACE1 and nicastrin, the protein level of BACE1 and nicastrin was unaltered (Figure S5), further indicating that $\alpha$-tocotrienol exerts its amyloidogenic potential by primarily directly affecting $\beta$ - and $\gamma$-secretase. The overproduction of $\mathrm{A} \beta$ peptides, as well as reduced $\mathrm{A} \beta$ clearance contribute to $\mathrm{AD}[54,58]$. Therefore, we analyzed whether $\alpha$-tocotrienol affects $A \beta$ degradation by incubating synthetic human $A \beta 40$ in the presence of $\alpha$-tocotrienol or the solvent on living cells for six hours and quantifying the remaining human $A \beta 40$ by Western blot analysis. In order to avoid the detection of $A \beta$ generated by the cells, we chose the mouse neuroblastoma cell line neuro 2a (N2a) and the antibody W02, recognizing human, but not mouse $\mathrm{A} \beta$ peptides, for this experiment (Figure 3F,G). In the presence of $\alpha$-tocotrienol, $\mathrm{A} \beta$ degradation was reduced to $82.1 \%(82.1 \% \pm 3.7 \%, p=0.003)$ (Figure $3 \mathrm{~F})$, indicating that $\alpha$-tocotrienol decreases $\mathrm{A} \beta$ degradation. Interestingly, in the presence of insulin, a competitive inhibitor of the IDE, one of the most important enzymes in $\mathrm{A} \beta$ degradation, tocotrienol, had no effect on $\mathrm{A} \beta$ degradation $(93.8 \% \pm 2.3 \%$, $p=0.09$ ) (Figure 3G). We therefore conclude that tocotrienol acts via a mechanism in $\mathrm{A} \beta$ degradation, in which IDE plays an essential role.

A: amyloidogenic pathway:

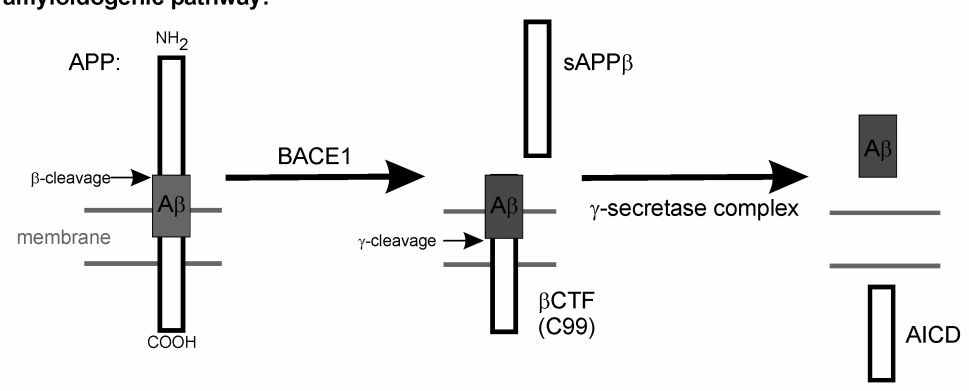

B:

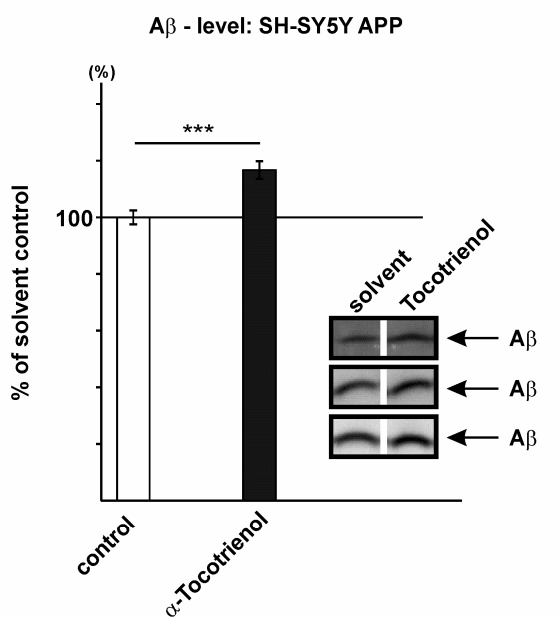

C:

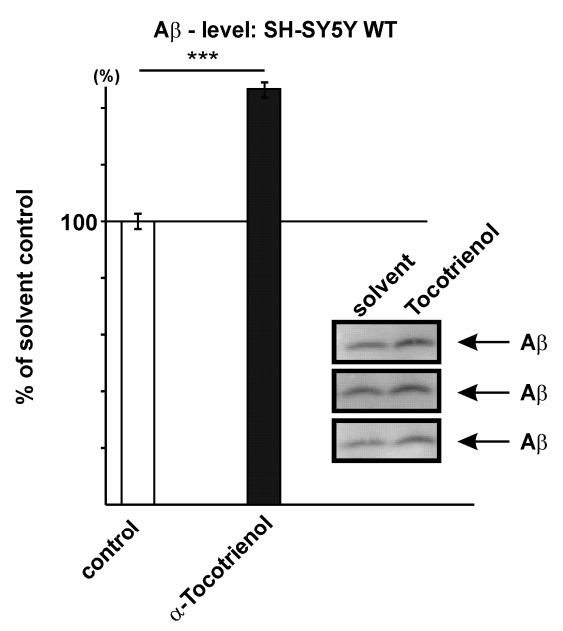

Figure 3. Cont. 
D:

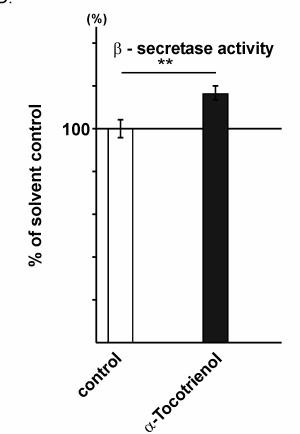

E:

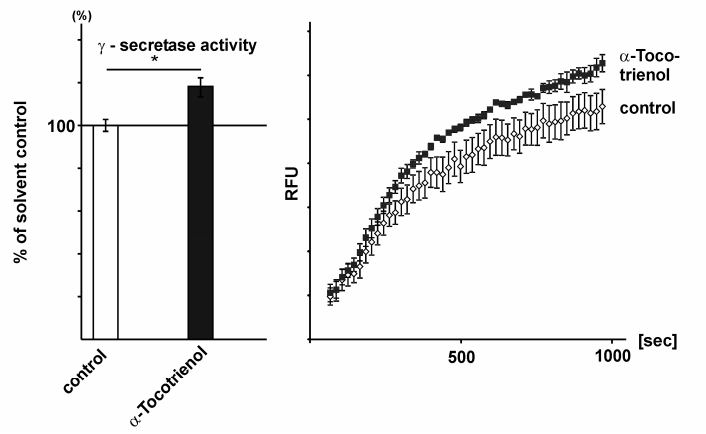

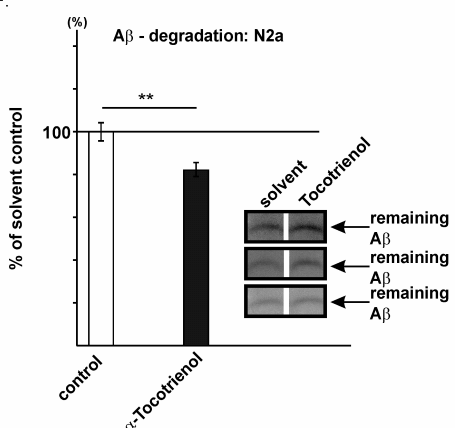

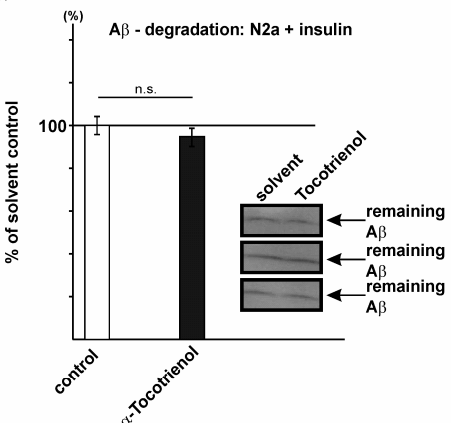

Figure 3. Effects of $\alpha$-tocotrienol on A $\beta$-homeostasis. (A) Overview of the amyloidogenic pathway resulting in A $\beta$ production; (B) enhanced secretion of A $\beta$ by SH-SY5Y APP695 transfected cells after incubation with $\alpha$-tocotrienol $(116.7 \% \pm 3.1 \%, p \leq 0.001, n=16)$. One hundred percent in the control cells corresponds to $8.9 \mathrm{ng} / \mathrm{mL}$ total A $\beta$; (C) elevated secretion of A $\beta$ by SH-SY5Y wildtype cells after incubation with $\alpha$-tocotrienol $(146.7 \% \pm 2.3 \%, p \leq 0.001, n=4)$. One hundred percent in the control cells equates to $3.1 \mathrm{ng} / \mathrm{mL}$ total $\mathrm{A} \beta$; (D) $\beta$-secretase activity in purified membranes of SH-SY5Y cells treated with $\alpha$-tocotrienol $(116.3 \% \pm 3.3 \%, p=0.01, n=6)$; (E) $\gamma$-secretase activity in purified membranes treated with $\alpha$-tocotrienol of SH-SY5Y cells $(118.3 \% \pm 4.5 \%, p=0.02, n=6)$; $(\mathbf{F}, \mathbf{G})$ Effects of tocopherols on $\mathrm{A} \beta$ degradation; $(\mathbf{F})$ increased protein level of non-degraded human $\mathrm{A} \beta$ or decreased $\mathrm{A} \beta$ degradation $(82.1 \% \pm 3.7 \%, p=0.003, n=6)$ in murine neuro $2 \mathrm{a}$ (N2a) cells incubated with $\alpha$-tocotrienol compared to the solvent; $(\mathbf{G})$ unaltered protein level of remaining human $\mathrm{A} \beta$ or unchanged $\mathrm{A} \beta$ degradation $(98.8 \% \pm 2.3 \%, p=0.09, n=6)$ in $\mathrm{N} 2$ a cells incubated with $10 \mu \mathrm{M}$ insulin in combination with $\alpha$-tocotrienol or the solvent. Statistical significance was calculated using a two-tailed Student's $t$-test $\left({ }^{*} p \leq 0.05,{ }^{* *} p \leq 0.01\right.$ and ${ }^{* * *} p \leq 0.001$, n.s., not significant).

\section{Discussion}

Vitamin $\mathrm{E}$ is a natural phyto-compound and frequently used as a nutritional supplement. Tocopherols are mainly found in vegetable oil, whereas the second family of vitamin E, the tocotrienols, is sourced from cereal grains and palm oil [59]. Tocopherols and tocotrienols are discussed to be important for successful aging, including cognitive performance [60]. Besides the well-known antioxidative activity of vitamin $\mathrm{E}$, molecules of the vitamin $\mathrm{E}$ family show neuroprotective, anti-inflammatory and cholesterol-lowering properties [28,33,40,41], mechanisms that are also important in the pathogenesis of AD [61]. Early studies already reported a hypocholesterolemic activity of synthetic and natural tocotrienols [28,30]. After the identification of the SREBP/SCAP system by the laboratory of Brown and Goldstein [62,63], more recent studies showed that members of the vitamin E family decrease the cellular cholesterol level by affecting the SREBP/SCAP system [44-46]. The SREBP/SCAP system is one of the main systems controlling the cellular cholesterol level. Briefly, when the cholesterol level is low, SREBP-2 (sterol regulatory element binding protein 2), which is tethered to the endoplasmic reticulum (ER) as a full-length protein, is escorted by SCAP (SREBP-2 cleavage activating protein) to the Golgi apparatus, where SREBP-2 is cleaved by site-1- and site-2-protease releasing the active N-terminal portion of SREBP-2, which migrates to the nucleus and 
upregulates genes involved in cholesterol synthesis and cholesterol uptake [62]. The resulting increased cholesterol level promotes binding of SCAP to Insig (insulin-induced gene), retaining full-length SREBP-2 in the ER. Song and DeBose-Boyd reported that $\delta$-tocotrienol blocks processing of SREBP-2 and stimulates HMGCR degradation, whereas $\gamma$-tocotrienol enhances primarily HMGCR degradation in SV589 cells, an immortalized line of human fibroblasts expressing the SV-40 large T-antigen [44]. $\alpha$-tocotrienol and all tocopherols showed no measurable effect on reductase degradation or SREBP processing [44]. However, $\alpha$-tocopherol has also been reported to decrease activated nuclear SREBP-2 resulting in a reduction of the expression of 10 genes involved in cholesterol de novo synthesis [45]. In line with this study, we found significantly decreased cholesterol level in the presence of $\alpha$-tocopherol in SH-SY5Y neuroblastoma cells: unesterified cholesterol was reduced to $93.4 \%$ and total cholesterol to $91.2 \%$. $\alpha$-tocotrienol treatment in human neuroblastoma cells resulted in an even more pronounced reduction in unesterified cholesterol and total cholesterol to $63.7 \%$ and $57.7 \%$, respectively. Notably, the reduction of total cholesterol and unesterified cholesterol level in $\alpha$-tocotrienol-treated cells was highly significant compared to $\alpha$-tocopherol, indicating that $\alpha$-tocotrienol has with respect to cholesterol and AD a more beneficial effect than $\alpha$-tocopherol. In line with our study, Krycer et al. [46] reported decreased SREBP-2 activity in the presence of $10 \mu \mathrm{M} \alpha$-tocotrienol by degrading mature SREBP-2. $\delta$ - and $\gamma$-tocotrienols were even more potent inhibitors of SREBP-2 than $\alpha$-tocotrienol [46]. This trend was also observed in the study by Song and DeBose-Boyd [44].

According to the cholesterol-lowering properties of tocopherols and tocotrienols, several studies reported a lower risk of mild cognitive impairment $(\mathrm{MCI})$ and $\mathrm{AD}$ in populations with elevated plasma levels of tocopherols and tocotrienols [64-67]. High dietary intake of the combination of all natural vitamin E congeners has been shown to exhibit protection against AD [68]. Dietary intake of mixed tocotrienols in subjects with cardiovascular risk factors and white matter lesions (WMLs) also revealed neuroprotective properties by reducing the progression of WMLs [69]. However, supplementing AD patients with vitamin E showed no clear beneficial effect on disease progress [70-72]. Meta-analysis of 135,967 participants in 19 clinical trials even revealed that high-doses ( $\geq 400 \mathrm{IU} / \mathrm{d}$ ) of vitamin $\mathrm{E}$ supplement may increase all-cause mortality [73]. Despite the observed cholesterol-lowering effect of $\alpha$-tocotrienol to approximately $60 \%$, we found an increase of the A $\beta$ level in $\alpha$-tocotrienol APP695 transfected SH-SY5Y cells to $116.7 \%$. Considering the cholesterol-lowering properties of $\alpha$-tocotrienol, one would expect that total $A \beta$ level should decrease, as cholesterol has been shown to increase $A \beta$ level $[17,18,20]$. However, we found that $\alpha$-tocotrienol has, besides the effect on cholesterol, a direct increasing effect on the secretases activities, resulting in an increased $A \beta$ production. Under the conditions used in this study, the $A \beta$ increasing effect of tocotrienol on the secretases was more pronounced than the $A \beta$ lowering effect of a reduced cholesterol level. However, we cannot rule out that under different experimental conditions, the cholesterol lowering effect is the more dominant effect on the $\mathrm{A} \beta$ level.

The total $A \beta$ level is increased by the direct effect of $\alpha$-tocotrienol on $\beta$ - and $\gamma$-secretase activity, as cell-free assays showed an increase in $\beta$-secretase activity to $116.3 \%$ and an elevation to $118.3 \%$ for $\gamma$-secretase, whereas gene transcription and protein level of $\beta$-secretase BACE1 and the components of the $\gamma$-secretase complex were unchanged. Besides directly affecting secretase activities, we found that $\alpha$-tocotrienol decreased $A \beta$ degradation to $82.1 \%$, also resulting in elevated $A \beta$ level. The inauspicious amyloidogenic potential of vitamin $E$ molecules accompanied by a reduction in $A \beta$ degradation was already shown in our previous study for tocopherols [42]. However, as vitamin E molecules exert different physiological activities, one cannot exclude that other indirect effects may also contribute to an increase in the $\mathrm{A} \beta$ level. Although vitamin E molecules function as an antioxidant, scavenging toxic free radicals discussed to contribute to the pathological processes of $\mathrm{AD}$, one has to take into consideration that elevated $A \beta$ levels in presence of tocopherols and tocotrienols might increase $A \beta$-induced oxidative stress [61,74]. Based on the multifaceted cellular mode of action of vitamin $\mathrm{E}$, one might speculate that some patients might profit from vitamin $\mathrm{E}$ supplementation, but others not. For example, individuals with hypercholesterolemia might profit from vitamin $\mathrm{E}$ 
because of the cholesterol-lowering effect of vitamin $\mathrm{E}$, whereas in individuals with normal or low cholesterol, the amyloid potential of tocopherols and tocotrienols predominates. On the other hand, individuals with a low plasma level of tocopherols and tocotrienols might also benefit from vitamin $\mathrm{E}$ supplementation. Nishida et al. have shown that depletion of vitamin E by crossing AD transgenic APP-Swedish mice with $\alpha$-tocopherol transfer protein knock-out mice increased A $\beta$ deposits in the brain, which was ameliorated with $\alpha$-tocopherol supplementation [75]. In line with these findings, dietary supplementation with $N$-acetylcysteine, $\alpha$-lipoic acid and $\alpha$-tocopherol attenuated age-related alterations in amyloid $\beta$ metabolism, an increase in APP, $\beta$-secretase activity and a decrease in the A $\beta$ degrading enzyme neprilysin, in aged rat brain [76] and prevented deficits in learning and memory functions [77]. On the other hand, treating MCI/AD patients with vitamin E revealed no significant differences in the rate of progression to $\mathrm{AD}$ between the vitamin $\mathrm{E}$ and placebo groups [70,71].

\section{Materials and Methods}

\subsection{Chemicals}

Chemicals including (+)- $\alpha$-tocopherol and (+)- $\alpha$-tocotrienol, as well as cell culture media were purchased from Sigma (Taufkirchen, Germany) unless otherwise noted.

\subsection{Cell Culture}

SH-SY5Y wildtype (wt) cells were cultivated in Dulbecco's Modified Eagle's Medium (DMEM) containing 10\% fetal calf serum (FCS) (PAN Biotech, Aidenbach, Germany). For SH-SY5Y APP (overexpressing the human APP695 isoform) and SH-SY5Y C99 cells (overexpressing the $\beta$-cleaved C-terminal fragment) [78], Hygromycin B (PAN Biotech) was supplemented in a final concentration of $0.3 \mathrm{mg} / \mathrm{mL}$.

Neuro 2a (N2a) cells were cultivated in DMEM comprising 10\% FCS, 1\% penicillin/streptomycin solution, $2 \mathrm{mM}$ L-glutamine, $0.1 \mathrm{mM}$ MEM and $1 \mathrm{mM}$ sodium-pyruvate.

Twelve hours before incubation, FCS in cell culture medium was reduced to $0.1 \%$.

Tocopherol and tocotrienol (dissolved in ethanol) were incubated in a concentration of $10 \mu \mathrm{M}$ in $0.1 \%$ FCS/DMEM for $24 \mathrm{~h}(8+16 \mathrm{~h})$; controls were treated with the appropriate ethanol concentration $(1 \%)$. Depending on subsequent experiments, cells were either lysed chemically in lysis buffer (0.1\% NP-40, 0.1\% Triton-X-100, $10 \mathrm{mM}$ Tris, $2 \mathrm{mM}$ EDTA) with or without protease inhibitor (Roche Diagnostics, Mannheim, Germany) or homogenized mechanically using a Minilys homogenizer (Peqlab, Erlangen, Germany).

\subsection{Cell Viability}

After incubation with tocopherol and tocotrienol, cell viability was identified by measuring lactate dehydrogenase activity using the Cytotoxicity Detection KitPLUS (Roche Diagnostics, Mannheim, Germany) according to the manufacturer's instructions.

\subsection{Cholesterol Concentration}

After long-term incubation for five days (3 days with 1\% FCS followed by treatment for $48 \mathrm{~h}$ in $0.1 \%$ FCS) with $10 \mu \mathrm{M}$ tocopherol and tocotrienol, cholesterol content in samples was measured by using the Amplex Red Cholesterol Assay Kit (Invitrogen, Karlsruhe, Germany) according to the manufacturer's protocol.

\subsection{Detection of Reactive Oxygen Species}

To detect ROS with aminophenyl fluorescein, cells were incubated on 96-well plates and washed once with prewarmed $\left(37^{\circ} \mathrm{C}\right)$ cell imaging solution $\left(140 \mathrm{mM} \mathrm{NaCl}, 2.5 \mathrm{mM} \mathrm{KCl}, 1.8 \mathrm{mM} \mathrm{CaCl}_{2}, 1 \mathrm{mM}\right.$ $\mathrm{MgCl}_{2}, 20 \mathrm{mM}$ HEPES, pH 7.4). On hundred microliters of aminophenyl fluorescein (Sigma Aldrich, Taufkirchen, Germany) in a final concentration of $10 \mu \mathrm{M}$ in cell imaging solution were added to each 
well. After incubation for $60 \mathrm{~min}$ in the dark at $37^{\circ} \mathrm{C}$, the plate was shaken for $60 \mathrm{~s}$, and fluorescence was measured with an excitation wavelength of $490 \pm 10 \mathrm{~nm}$ and an emission wavelength of $515 \pm 10 \mathrm{~nm}$ using a Safire ${ }^{2}$ Fluorometer (Tecan, Crailsheim, Germany).

To evaluate the antioxidative potential of $\alpha$-tocopherol and $\alpha$-tocotrienol against hydrogen peroxide, parts of the Amplex Red Cholesterol Assay Kit (Invitrogen) were used. Cells were incubated on 96-well plates with the addition of $1 \mu \mathrm{M} \mathrm{H}_{2} \mathrm{O}_{2}$ and washed with warmed phosphate-buffered saline. Fifty microliters $1 \times$ reaction buffer $(0.1 \mathrm{M}$ potassium phosphate, $50 \mathrm{mM} \mathrm{NaCl}, 5 \mathrm{mM}$ cholic acid, $0.1 \%$ Triton X-100, pH 7.4) were added to each well, and the plate was sonificated for $10 \mathrm{~s}$. Afterwards, $50 \mu \mathrm{L} 1 \times$ reaction buffer containing $300 \mu \mathrm{M}$ Amplex Red reagent and $2 \mathrm{U} / \mathrm{mL}$ horseradish peroxidase were pipetted to each sample, and the plate was shaken for $60 \mathrm{~s}$. Ten microliters of $10 \mu \mathrm{M} \mathrm{H}_{2} \mathrm{O}_{2}$ were added to each well and mixed by shaking. The plate was incubated $40 \mathrm{~min}$ under light exclusion at $37^{\circ} \mathrm{C}$, shaken for another $60 \mathrm{~s}$, and fluorescence was measured with an excitation wavelength of $540 \pm 10 \mathrm{~nm}$ and an emission wavelength of $590 \pm 10 \mathrm{~nm}$.

\subsection{Determination of Protein Concentration}

Protein concentration in samples was determined with bicinchoninic acid as described in [79]. Before conducting the experiments, samples were adjusted to equal protein concentrations.

\subsection{Western Blot Analysis}

The total protein concentration in samples was measured and equaled as mentioned above. Sodium dodecyl sulfate polyacrylamide gel electrophoresis (SDS-PAGE) was performed with $10 \%-20 \%$ Tricine gradient gels (Anamed, Groß-Bieberau, Germany). Afterwards, proteins were transferred onto nitrocellulose membranes (Whatman, Dassel, Germany), and the following antibodies were used for Western blot (WB) analysis: W02 antibody $(5 \mu \mathrm{g} / \mathrm{mL})$ (Millipore, Billerica, MA, USA), anti-BACE1 (B0806) (1:1000, Sigma), anti-nicastrin 1 (1:500, sc25648) (Santa Cruz, Dallas, TX, USA) and anti-sAPP $\beta$ (1:250, MBS492139) (MyBioSource, San Diego, CA, USA) as primary antibodies; anti-rabbit (W401B) (1:5000, Promega, Mannheim, Germany) and anti-mouse (P0260) (1:10,000, Dako, Hamburg, Germany) as secondary antibodies.

Analysis of the $A \beta$ protein level was performed as described earlier [80]. For detection in WB analysis, A $\beta$ was immunoprecipitated with $20 \mu \mathrm{L}$ protein G-Sepharose (Sigma) and W02 antibody $(5 \mu \mathrm{g} / \mathrm{mL})$. A $\beta$ peptides were detected by the use of W02 in WB. The specificity, sensitivity and linearity of this assay were validated in Ida et al. [80]. Previously, we additionally confirmed the specificity, sensitivity and linearity of A $\beta$ detection by using the W02 antibody under our experimental conditions [81].

Proteins were detected by the enhanced chemiluminescense (ECL)-method (Perkin Elmer, Rodgau-Jügesheim, Germany) and densitometrically quantified with Image Gauge V3.45 software (Fujifilm, Düsseldorf, Germany).

\subsection{Preparation of Purified Membranes}

The preparation of purified membranes was conducted according to [82]: after washing three times with precooled $\left(4^{\circ} \mathrm{C}\right)$ phosphate buffered saline (PBS), SH-SY5Y wt cells were scraped in sucrose buffer (10 mM Tris/HCl, pH 7.4, 1 mM EDTA, $200 \mathrm{mM}$ sucrose) and homogenized using a Minilys homogenizer (Peqlab) at maximum speed for $30 \mathrm{~s}$. Total protein amount was measured and equaled as mentioned above. Samples were centrifuged at 900 relative centrifugal force ( $\mathrm{rcf}$ ) for $10 \mathrm{~min}$ at $4{ }^{\circ} \mathrm{C}$; supernatants were collected in a new tube and centrifuged again (Optima MAX Ultracentrifuge, Beckman Coulter, Krefeld, Germany) for $75 \mathrm{~min}$ at 55,000 rpm and $4{ }^{\circ} \mathrm{C}$. Pellets were resuspended in sucrose buffer at medium speed for $10 \mathrm{~s}$ using Minilys (Peqlab). 


\subsection{Measurement of $\beta$ - and $\gamma$-Secretase Activity}

Evaluation of $\beta$ - and $\gamma$-secretase activity has been described in detail earlier [20]. Shortly, fluorogenic $\beta$-secretase substrate IV (Calbiochem, Darmstadt, Germany) or $\gamma$-secretase substrate (Calbiochem) was added in a final concentration of 20 or $10 \mu \mathrm{M}$ to samples, respectively. In the case of $\beta$-secretase, the resulting fluorescence was measured continuously under light exclusion with a Safire2 Fluorometer (Tecan) at an excitation wavelength of $345 \pm 5 \mathrm{~nm}$ and an emission wavelength of $500 \pm 2.5 \mathrm{~nm}$, for $\gamma$-secretase at an excitation wavelength of $355 \pm 10 \mathrm{~nm}$ and an emission wavelength of $440 \pm 10 \mathrm{~nm}$.

\subsection{Measurement of Secretase Activity in Living Cells}

SH-SY5Y wt cells were incubated with tocopherol and tocotrienol and washed with prewarmed cell imaging solution (140 mM NaCl, $5 \mathrm{mM} \mathrm{KCl}, 8 \mathrm{mM} \mathrm{CaCl}_{2}, 1 \mathrm{mM} \mathrm{MgCl}_{2}, 20 \mathrm{mM}$ HEPES, pH 7.4). Thirty micromolar fluorogenic $\beta$-secretase substrate (Calbiochem) or $12 \mu \mathrm{M} \gamma$-secretase substrate (Calbiochem) in $50 \mu \mathrm{L}$ of cell imaging solution was added, and fluorescence was determined under light exclusion at $37^{\circ} \mathrm{C}$ in a Safire2 Fluorometer (Tecan) with excitation wavelengths of $345 \pm 5 \mathrm{~nm}$ and $355 \pm 10 \mathrm{~nm}$ and emission wavelengths of $500 \pm 2.5$ and $440 \pm 10 \mathrm{~nm}$, respectively [42].

\subsection{Quantitative Real-Time Experiments}

SH-SY5Y wt cells were incubated as mentioned above and TRIzol reagent (Invitrogen) was used to isolate total RNA, of which $2 \mu \mathrm{g}$ were used in reverse transcription with the High-Capacity cDNA Reverse Transcription Kit (Life Technologies, Darmstadt, Germany). Fast SYBR Green Master Mix (Applied Biosystems, Darmstadt, Germany) was utilized for quantitative real-time polymerase chain reaction on a Piko Real-Time PCR System (Thermo Scientific, Waltham, MA, USA). Experiments were carried out according to the manufacturers' protocols. Data evaluation and primer sequences are described in detail in [42].

\subsection{Determination of Total A $\beta$ Degradation}

Evaluation of $A \beta$ degradation has been described earlier [42]. Before incubation, N2a wt cells were cultivated for $6 \mathrm{~h}$ with reduced FCS (0.1\%). Subsequently, tocopherol and tocotrienol (10 $\mu \mathrm{M})$ were applied to the cells for $18 \mathrm{~h}$ followed by an additional treatment for $6 \mathrm{~h}$ with tocopherol and tocotrienol in combination with $0.5 \mu \mathrm{g} / \mathrm{mL}$ human synthetic $\mathrm{A} \beta 40$. To inhibit the activity of IDE [83], cells were additionally incubated with $10 \mu \mathrm{M}$ human insulin (Sigma). Non-degraded human A $\beta 40$ from cell culture supernatant was separated in SDS-PAGE and detected by Western blotting using the W02 antibody as described above.

\subsection{Tocopherol and Tocotrienol Uptake}

For quantification of $\alpha$-tocopherol and $\alpha$-tocotrienol in control samples, we pooled 5 independent control samples. The standard addition method with $0.02,0.05,0.1,0.2,1$ and $2 \mathrm{nmol} / \mathrm{mg}$ protein of $\alpha$-tocopherol and $\alpha$-tocotrienol was used to calculate calibration curves $\left(R^{2}>0.97\right)$. The resulting control sample concentration of $\alpha$-tocopherol was $0.067 \pm 0.031 \mathrm{nmol} / \mathrm{mg}$ protein and for $\alpha$-tocotrienol $0.034 \pm 0.005 \mathrm{nmol} / \mathrm{mg}$ protein.

Tocopherols and tocotrienols were significantly $(>500 \%, p \leq 0.001)$ taken up by cells. Analyses were performed by mass spectrometry (see below): isotopically-labeled $( \pm) \mathrm{d}_{6}$ - $\alpha$-tocopherol, HPLC-grade ethyl acetate and HPLC-MS-grade acetonitrile were purchased from Sigma-Aldrich (Steinheim, Germany); 2,6-di-tert-butyl-4-methylphenol (butylhydroxytoluene, BHT) from Merck Schuchardt OHG (Hohenbrunn, Germany); ascorbic acid and sodium hydroxide from Carl Roth GmbH (Karlsruhe, Germany); HPLC-grade dichloromethane and HPLC-grade water from VWR International (Darmstadt, Germany); analytical reagent grade $n$-hexane from Fischer Scientific UK 
(Loughboroug, UK); sodium hydroxide and 37\% hydrochloric acid from Merck (Darmstadt, Germany); and formic acid from AppliChem (Darmstadt, Germany).

\subsubsection{Sample Preparation}

For extraction, we used saponification combined with liquid/liquid extraction. This combination is widely used in the literature to extract tocopherols from biological samples [48,84].

All extractions were carried out in triplicate from three independent $10-\mathrm{cm}$ culture dishes, which were incubated for $24 \mathrm{~h}(8+16 \mathrm{~h})$, as described before with $10 \mu \mathrm{M} \alpha$-tocopherol, $10 \mu \mathrm{M} \alpha$-tocotrienol and ethanol as the control.

Prior to extraction, the culture medium was removed; cells were washed three times with $1 \mathrm{~mL}$ of water and dissolved in $200 \mu \mathrm{L}$ of water. The cells were homogenized using glass beads in Minilys (Peqlab) for $30 \mathrm{~s}$ at maximum speed and diluted to a protein concentration of $10 \mathrm{mg} / \mathrm{mL}$.

The following solvents were used for extraction: (A) internal standard solution of $20 \mu \mathrm{M}$ $d_{6}-\alpha$-tocopherol and $0.1 \%(w / w)$ BHT in acetonitrile; (B) $1.14 \mathrm{M}$ ascorbic acid and $1.14 \mathrm{M}$ sodium hydroxide in water/methanol 2:1 $(v / v)$; (C) $10 \mathrm{M}$ sodium hydroxide in water/methanol 2:1 $(v / v)$; (D) $3.2 \mathrm{M}$ hydrochloric acid in water/acetonitrile 2:3 $(v / v)$; and (E) extraction solution dichloromethane/ethyl acetate/n-hexane 6:1:1 $(v / v)$. For extraction, $30 \mu \mathrm{L}$ of the homogenized cell sample at a $10-\mathrm{mg} / \mathrm{mL}$ protein concentration were mixed with $15 \mu \mathrm{L}$ internal standard solution (A); $20 \mu \mathrm{L}$ of solution (B) and $20 \mu \mathrm{L}$ of solution (C) were added and the mixture saponificated at $55^{\circ} \mathrm{C}$ under horizontal shaking conditions at $800 \mathrm{rpm}$ for $20 \mathrm{~min}$ (Eppendorf Thermomixer, Hamburg, Germany). This was followed by cooling on ice, adding $60 \mu \mathrm{L}$ of solution (D) and $330 \mu \mathrm{L}$ of extraction solution (E). To achieve extraction equilibrium, the mixture was shaken for $20 \mathrm{~min}$ at $400 \mathrm{rpm}$, the organic layer removed, dried under a gentle stream of nitrogen and the residue dissolved in $200 \mu \mathrm{L}$ of acetonitrile.

\subsubsection{LC-MS/MS}

For LC-MS/MS analysis, $1 \mu \mathrm{L}$ of the extract was injected into an Agilent (Santa Clara, CA, USA) 1200 Series capillary HPLC system. An Agilent Zorbax SB-C18 column was used for separation at a $20 \mu \mathrm{L} / \mathrm{min}$ isocratic flow rate of $100 \%$ acetonitrile $(+0.1 \%$ formic acid). The column temperature was set to $25^{\circ} \mathrm{C}$ in a MayLab (Vienna, Austria) Mistra-Switch column oven. Retention times under these conditions were $1.9 \mathrm{~min}$ for $\alpha$-tocotrienol and $4.5 \mathrm{~min}$ for tocopherol. Detection of $\alpha$-tocotrienol and $\alpha$-tocopherol was achieved on a Sciex (Concord, ON, Canada) QTRAP 4000 triple quadrupole mass spectrometer in positive electrospray ionization (ESI) mode using selected reaction monitoring (SRM). The MS conditions were as follows: spray voltage, $5500 \mathrm{~V}$; source temperature, $120^{\circ} \mathrm{C}$; curtain gas, 27 psi; Gas 1, 25 psi; Gas 2, 25 psi; entrance potential, 10 V; collision exit potential, 14 V; interface heater, on; declustering potential (DP) and collision energy (CE), compound specific. SRM-transition was $m / z 423.3 \rightarrow 165.1$ for $\alpha$-tocotrienol $(\mathrm{CE}=27 \mathrm{~V}, \mathrm{DP}=55 \mathrm{~V}) ; m / z 429.4 \rightarrow 165.1$ for $\alpha$-tocopherol $(\mathrm{CE}=33 \mathrm{~V}, \mathrm{DP}=80 \mathrm{~V})$; and $m / z 435.4 \rightarrow 171.1$ for $\mathrm{d}_{6}-\alpha$-tocopherol $(\mathrm{CE}=33 \mathrm{~V}, \mathrm{DP}=80 \mathrm{~V})$. For all SRM transitions, dwell-times were $200 \mathrm{~ms}$. Under ESI conditions, the formation of $[\mathrm{M}-\mathrm{H}]^{+}$ions after hydride abstraction from the analyte molecules was unusual; however, a similar behavior was reported for tocopherol under atmospheric pressure chemical ionization (APCI) conditions [85]. This ion was used as the precursor ion for SRM, as it formed the base peak in the collision-induced dissociation (CID) spectra under the described conditions.

\subsection{Statistical Analysis}

Data are illustrated as an average of at least three independent experiments, instead of; the exact $n$-number for each experiment is listed in the figure legend. Error bars show the standard deviation of the mean. A two-tailed Student's $t$-test was used for calculating statistical significance, which was set at ${ }^{*} p \leq 0.05,{ }^{* *} p \leq 0.01$ and ${ }^{* * *} p \leq 0.001$. For multiple comparison analysis of the different vitamin $\mathrm{E}$ species, post hoc ANOVA was conducted. 


\section{Conclusions}

In summary, we could show that $\alpha$-tocopherol and $\alpha$-tocotrienol showed a nearly identical beneficial effect regarding the formation of ROS, whereas $\alpha$-tocotrienol revealed an even more pronounced effect in the reduction of cholesterol level. Both, reduced ROS/lipid peroxidation and reduced cholesterol level are beneficial for AD (Figure 4). However, $\alpha$-tocotrienol and tocopherols increase the release of $\mathrm{A} \beta$ by increased amyloidogenic APP processing and decrease the degradation of $A \beta$ leading to the formation of neuritic plaques. Indisputable positive effects, but also negative modes of action of the vitamin $\mathrm{E}$ family with respect to the mechanisms involved in AD pathogenesis have to be taken into consideration when deciding whether patients could benefit from vitamin $\mathrm{E}$ supplementation or not.

$\begin{array}{ll}\text { potential protective effects } & \text { potential negative effects } \\ \text { of tocotrienol } & \text { of tocotrienol }\end{array}$

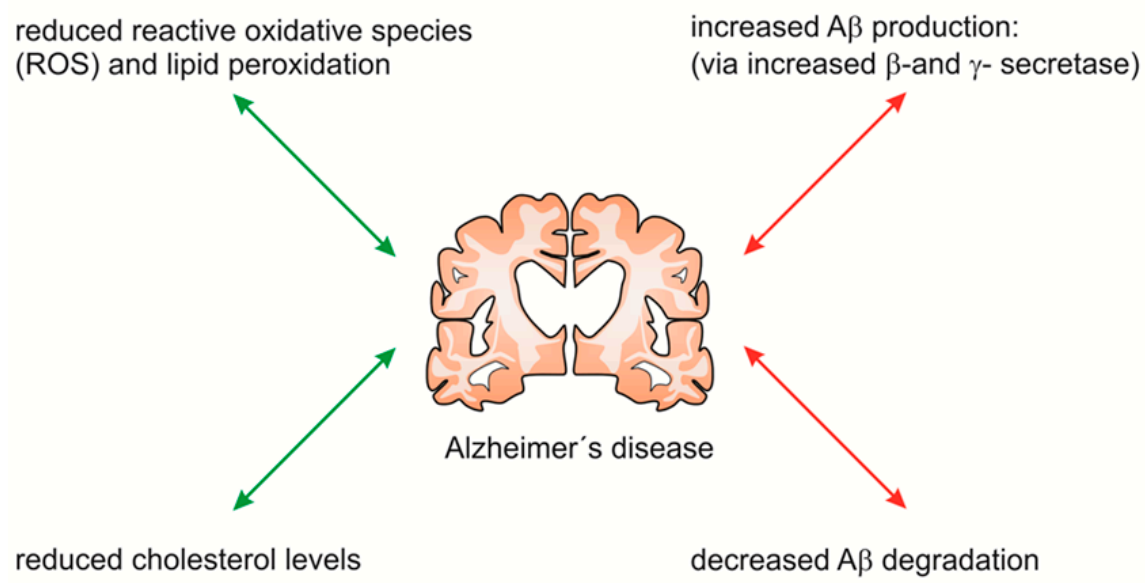

Figure 4. Summary of the effects of $\alpha$-tocotrienol on Alzheimer's-relevant processes. On the one hand, $\alpha$-tocotrienol has positive effects by decreasing cholesterol levels and reactive oxidative, instead of; on the other hand, $\alpha$-tocotrienols accelerate the amyloidogenic pathway and decrease $\mathrm{A} \beta$ degradation.

Supplementary Materials: Supplementary materials can be found at www.mdpi.com/1422-0067/17/11/1809/s1.

Acknowledgments: According to the author guidelines, funding for the research leading to these results were received from: the EU FP7 project LipiDiDiet, Grant Agreement No. 211696. Moreover, funding for MG and TH was provided by Fundació la Maratò de TV3 20140931 and by JPND (EU Joint Programme-Neurodegenerative Disease Research) MindAD 1ED1508.

Author Contributions: Liesa Regner, Christoph P. Stahlmann, Janine Mett, Christopher Nelke, Olga Streidenberger, Andrea Thiel, Shatha R. Zaidan, Hannah Stoetzel, Pascal Schorr, Jakob Winkler and Heike S. Grimm performed the experiments. Marcus O. W. Grimm, Heike S. Grimm, Kristina Endres, Tobias Hartmann and Dietrich A. Volmer wrote the manuscript. Marcus O. W. Grimm and Tobias Hartmann designed the study.

Conflicts of Interest: The authors declare no conflict of interest.

\section{References}

1. Masters, C.L.; Simms, G.; Weinman, N.A.; Multhaup, G.; McDonald, B.L.; Beyreuther, K. Amyloid plaque core protein in Alzheimer disease and Down syndrome. Proc. Natl. Acad. Sci. USA 1985, 82, 4245-4249. [CrossRef] [PubMed]

2. Haass, C. Take five-Bace and the $\gamma$-secretase quartet conduct Alzheimer's amyloid $\beta$-peptide generation. EMBO J. 2004, 23, 483-488. [CrossRef] [PubMed]

3. Grundke-Iqbal, I.; Iqbal, K.; Quinlan, M.; Tung, Y.C.; Zaidi, M.S.; Wisniewski, H.M. Microtubule-associated protein tau. A component of Alzheimer paired helical filaments. J. Biol. Chem. 1986, 261, 6084-6089. [PubMed] 
4. Kayed, R.; Head, E.; Thompson, J.L.; McIntire, T.M.; Milton, S.C.; Cotman, C.W.; Glabe, C.G. Common structure of soluble amyloid oligomers implies common mechanism of pathogenesis. Science 2003, 300, 486-489. [CrossRef] [PubMed]

5. Shankar, G.M.; Li, S.; Mehta, T.H.; Garcia-Munoz, A.; Shepardson, N.E.; Smith, I.; Brett, F.M.; Farrell, M.A.; Rowan, M.J.; Lemere, C.A.; et al. Amyloid- $\beta$ protein dimers isolated directly from Alzheimer's brains impair synaptic plasticity and memory. Nat. Med. 2008, 14, 837-842. [CrossRef] [PubMed]

6. Demuro, A.; Parker, I.; Stutzmann, G.E. Calcium signaling and amyloid toxicity in Alzheimer disease. J. Biol. Chem. 2010, 285, 12463-12468. [CrossRef] [PubMed]

7. Jomova, K.; Vondrakova, D.; Lawson, M.; Valko, M. Metals, oxidative stress and neurodegenerative disorders. Mol. Cell. Biochem. 2010, 345, 91-104. [CrossRef] [PubMed]

8. Mandrekar-Colucci, S.; Landreth, G.E. Microglia and inflammation in Alzheimer's disease. CNS Neurol. Disord. Drug Targets 2010, 9, 156-167. [CrossRef] [PubMed]

9. Fedrizzi, L.; Carafoli, E. $\mathrm{Ca}^{2+}$ dysfunction in neurodegenerative disorders: Alzheimer's disease. BioFactors 2011, 37, 189-196. [CrossRef] [PubMed]

10. Gotz, J.; Eckert, A.; Matamales, M.; Ittner, L.M.; Liu, X. Modes of abeta toxicity in Alzheimer's disease. Cell. Mol. Life Sci. 2011, 68, 3359-3375. [CrossRef] [PubMed]

11. Corder, E.H.; Saunders, A.M.; Strittmatter, W.J.; Schmechel, D.E.; Gaskell, P.C.; Small, G.W.; Roses, A.D.; Haines, J.L.; Pericak-Vance, M.A. Gene dose of apolipoprotein E type 4 allele and the risk of Alzheimer's disease in late onset families. Science 1993, 261, 921-923. [CrossRef] [PubMed]

12. Kivipelto, M.; Helkala, E.L.; Laakso, M.P.; Hanninen, T.; Hallikainen, M.; Alhainen, K.; Soininen, H.; Tuomilehto, J.; Nissinen, A. Midlife vascular risk factors and Alzheimer's disease in later life: Longitudinal, population based study. Br. Med. J. 2001, 322, 1447-1451. [CrossRef]

13. Refolo, L.M.; Malester, B.; LaFrancois, J.; Bryant-Thomas, T.; Wang, R.; Tint, G.S.; Sambamurti, K.; Duff, K.; Pappolla, M.A. Hypercholesterolemia accelerates the Alzheimer's amyloid pathology in a transgenic mouse model. Neurobiol. Dis. 2000, 7, 321-331. [CrossRef] [PubMed]

14. Shie, F.S.; Jin, L.W.; Cook, D.G.; Leverenz, J.B.; LeBoeuf, R.C. Diet-induced hypercholesterolemia enhances brain A $\beta$ accumulation in transgenic mice. Neuroreport 2002, 13, 455-459. [CrossRef] [PubMed]

15. Refolo, L.M.; Pappolla, M.A.; LaFrancois, J.; Malester, B.; Schmidt, S.D.; Thomas-Bryant, T.; Tint, G.S.; Wang, R.; Mercken, M.; Petanceska, S.S.; et al. A cholesterol-lowering drug reduces $\beta$-amyloid pathology in a transgenic mouse model of Alzheimer's disease. Neurobiol. Dis. 2001, 8, 890-899. [CrossRef] [PubMed]

16. Sparks, D.L.; Kuo, Y.M.; Roher, A.; Martin, T.; Lukas, R.J. Alterations of Alzheimer's disease in the cholesterol-fed rabbit, including vascular inflammation. Preliminary observations. Ann. N. Y. Acad. Sci. 2000, 903, 335-344. [CrossRef] [PubMed]

17. Fassbender, K.; Simons, M.; Bergmann, C.; Stroick, M.; Lutjohann, D.; Keller, P.; Runz, H.; Kuhl, S.; Bertsch, T.; von Bergmann, K.; et al. Simvastatin strongly reduces levels of Alzheimer's disease $\beta$-amyloid peptides A $\beta$ 42 and A $\beta 40$ in vitro and in vivo. Proc. Natl. Acad. Sci. USA 2001, 98, 5856-5861. [CrossRef] [PubMed]

18. Simons, M.; Keller, P.; De Strooper, B.; Beyreuther, K.; Dotti, C.G.; Simons, K. Cholesterol depletion inhibits the generation of $\beta$-amyloid in hippocampal neurons. Proc. Natl. Acad. Sci. USA 1998, 95, 6460-6464. [CrossRef] [PubMed]

19. Wahrle, S.; Das, P.; Nyborg, A.C.; McLendon, C.; Shoji, M.; Kawarabayashi, T.; Younkin, L.H.; Younkin, S.G.; Golde, T.E. Cholesterol-dependent $\gamma$-secretase activity in buoyant cholesterol-rich membrane microdomains. Neurobiol. Dis. 2002, 9, 11-23. [CrossRef] [PubMed]

20. Grimm, M.O.; Grimm, H.S.; Tomic, I.; Beyreuther, K.; Hartmann, T.; Bergmann, C. Independent inhibition of Alzheimer disease $\beta$ - and $\gamma$-secretase cleavage by lowered cholesterol levels. J. Biol. Chem. 2008, 283, 11302-11311. [CrossRef] [PubMed]

21. Xiong, H.; Callaghan, D.; Jones, A.; Walker, D.G.; Lue, L.F.; Beach, T.G.; Sue, L.I.; Woulfe, J.; Xu, H.; Stanimirovic, D.B.; et al. Cholesterol retention in Alzheimer's brain is responsible for high $\beta$ - and $\gamma$-secretase activities and A $\beta$ production. Neurobiol. Dis. 2008, 29, 422-437. [CrossRef] [PubMed]

22. Haag, M.D.; Hofman, A.; Koudstaal, P.J.; Stricker, B.H.; Breteler, M.M. Statins are associated with a reduced risk of Alzheimer disease regardless of lipophilicity. The rotterdam study. J. Neurol. Neurosurg. Psychiatry 2009, 80, 13-17. [CrossRef] [PubMed] 
23. Wolozin, B.; Kellman, W.; Ruosseau, P.; Celesia, G.G.; Siegel, G. Decreased prevalence of Alzheimer disease associated with 3-hydroxy-3-methyglutaryl coenzyme a reductase inhibitors. Arch. Neurol. 2000, 57, 1439-1443. [CrossRef] [PubMed]

24. Wolozin, B.; Wang, S.W.; Li, N.C.; Lee, A.; Lee, T.A.; Kazis, L.E. Simvastatin is associated with a reduced incidence of dementia and Parkinson's disease. BMC Med. 2007, 5, 20-31. [CrossRef] [PubMed]

25. Rea, T.D.; Breitner, J.C.; Psaty, B.M.; Fitzpatrick, A.L.; Lopez, O.L.; Newman, A.B.; Hazzard, W.R.; Zandi, P.P.; Burke, G.L.; Lyketsos, C.G.; et al. Statin use and the risk of incident dementia: The cardiovascular health study. Arch. Neurol. 2005, 62, 1047-1051. [CrossRef] [PubMed]

26. Feldman, H.H.; Doody, R.S.; Kivipelto, M.; Sparks, D.L.; Waters, D.D.; Jones, R.W.; Schwam, E.; Schindler, R.; Hey-Hadavi, J.; DeMicco, D.A.; et al. Randomized controlled trial of atorvastatin in mild to moderate Alzheimer disease: Leade. Neurology 2010, 74, 956-964. [CrossRef] [PubMed]

27. Sano, M.; Bell, K.L.; Galasko, D.; Galvin, J.E.; Thomas, R.G.; van Dyck, C.H.; Aisen, P.S. A randomized, double-blind, placebo-controlled trial of simvastatin to treat Alzheimer disease. Neurology 2011, 77, 556-563. [CrossRef] [PubMed]

28. Pearce, B.C.; Parker, R.A.; Deason, M.E.; Qureshi, A.A.; Wright, J.J. Hypocholesterolemic activity of synthetic and natural tocotrienols. J. Med. Chem. 1992, 35, 3595-3606. [CrossRef] [PubMed]

29. Qureshi, A.A.; Bradlow, B.A.; Brace, L.; Manganello, J.; Peterson, D.M.; Pearce, B.C.; Wright, J.J.; Gapor, A.; Elson, C.E. Response of hypercholesterolemic subjects to administration of tocotrienols. Lipids 1995, 30, 1171-1177. [CrossRef] [PubMed]

30. Parker, R.A.; Pearce, B.C.; Clark, R.W.; Gordon, D.A.; Wright, J.J. Tocotrienols regulate cholesterol production in mammalian cells by post-transcriptional suppression of 3-hydroxy-3-methylglutaryl-coenzyme a reductase. J. Biol. Chem. 1993, 268, 11230-11238. [PubMed]

31. Qureshi, A.A.; Qureshi, N.; Hasler-Rapacz, J.O.; Weber, F.E.; Chaudhary, V.; Crenshaw, T.D.; Gapor, A.; Ong, A.S.; Chong, Y.H.; Peterson, D.; et al. Dietary tocotrienols reduce concentrations of plasma cholesterol, apolipoprotein B, thromboxane B2, and platelet factor 4 in pigs with inherited hyperlipidemias. Am. J. Clin. Nutr. 1991, 53, 1042-1046.

32. Xia, W.; Mo, H. Potential of tocotrienols in the prevention and therapy of Alzheimer's disease. J. Nutr. Biochem. 2016, 31, 1-9. [CrossRef] [PubMed]

33. Brigelius-Flohe, R.; Traber, M.G. Vitamin E: Function and metabolism. FASEB J. 1999, 13, $1145-1155$. [PubMed]

34. Ricciarelli, R.; Argellati, F.; Pronzato, M.A.; Domenicotti, C. Vitamin E and neurodegenerative diseases. Mol. Asp. Med. 2007, 28, 591-606. [CrossRef] [PubMed]

35. La Fata, G.; Weber, P.; Mohajeri, M.H. Effects of vitamin E on cognitive performance during ageing and in Alzheimer's disease. Nutrients 2014, 6, 5453-5472. [CrossRef] [PubMed]

36. Mangialasche, F.; Polidori, M.C.; Monastero, R.; Ercolani, S.; Camarda, C.; Cecchetti, R.; Mecocci, P. Biomarkers of oxidative and nitrosative damage in Alzheimer's disease and mild cognitive impairment. Ageing Res. Rev. 2009, 8, 285-305. [CrossRef] [PubMed]

37. Muid, S.; Froemming, G.R.; Rahman, T.; Ali, A.M.; Nawawi, H.M. $\delta$ - and $\gamma$-tocotrienol isomers are potent in inhibiting inflammation and endothelial activation in stimulated human endothelial cells. Food Nutr. Res. 2016, 60, 31526-31537. [CrossRef] [PubMed]

38. Wong, W.Y.; Ward, L.C.; Fong, C.W.; Yap, W.N.; Brown, L. Anti-inflammatory $\gamma$ - and $\delta$-tocotrienols improve cardiovascular, liver and metabolic function in diet-induced obese rats. Eur. J. Nutr. 2015. [CrossRef] [PubMed]

39. Wu, S.J.; Liu, P.L.; Ng, L.T. Tocotrienol-rich fraction of palm oil exhibits anti-inflammatory property by suppressing the expression of inflammatory mediators in human monocytic cells. Mol. Nutr. Food Res. 2008, 52, 921-929. [CrossRef] [PubMed]

40. Reiter, E.; Jiang, Q.; Christen, S. Anti-inflammatory properties of $\alpha$ - and $\gamma$-tocopherol. Mol. Asp. Med. 2007, 28, 668-691. [CrossRef] [PubMed]

41. Jiang, Q. Natural forms of vitamin E: Metabolism, antioxidant, and anti-inflammatory activities and their role in disease prevention and therapy. Free Radic. Biol. Med. 2014, 72, 76-90. [CrossRef] [PubMed] 
42. Grimm, M.O.; Stahlmann, C.P.; Mett, J.; Haupenthal, V.J.; Zimmer, V.C.; Lehmann, J.; Hundsdorfer, B.; Endres, K.; Grimm, H.S.; Hartmann, T. Vitamin E: Curse or benefit in Alzheimer's disease? A systematic investigation of the impact of $\alpha-, \gamma$ - and $\delta$-tocopherol on ass generation and degradation in neuroblastoma cells. J. Nutr. Health Aging 2015, 19, 646-656. [CrossRef] [PubMed]

43. Fairus, S.; Nor, R.M.; Cheng, H.M.; Sundram, K. $\alpha$-tocotrienol is the most abundant tocotrienol isomer circulated in plasma and lipoproteins after postprandial tocotrienol-rich vitamin E supplementation. Nutr. J. 2012, 11, 5-16. [CrossRef] [PubMed]

44. Song, B.L.; DeBose-Boyd, R.A. Insig-dependent ubiquitination and degradation of 3-hydroxy-3-methylglutaryl coenzyme a reductase stimulated by $\delta$ - and $\gamma$-tocotrienols. J. Biol. Chem. 2006, 281, 25054-25061. [CrossRef] [PubMed]

45. Valastyan, S.; Thakur, V.; Johnson, A.; Kumar, K.; Manor, D. Novel transcriptional activities of vitamin E: Inhibition of cholesterol biosynthesis. Biochemistry 2008, 47, 744-752. [CrossRef] [PubMed]

46. Krycer, J.R.; Phan, L.; Brown, A.J. A key regulator of cholesterol homoeostasis, SREBP-2, can be targeted in prostate cancer cells with natural products. Biochem. J. 2012, 446, 191-201. [CrossRef] [PubMed]

47. Chang, T.Y.; Chang, C.C.; Bryleva, E.; Rogers, M.A.; Murphy, S.R. Neuronal cholesterol esterification by acat1 in Alzheimer's disease. IUBMB Life 2010, 62, 261-267. [CrossRef] [PubMed]

48. Craft, N.E.; Haitema, T.B.; Garnett, K.M.; Fitch, K.A.; Dorey, C.K. Carotenoid, tocopherol, and retinol concentrations in elderly human brain. J. Nutr. Health Aging 2004, 8, 156-162. [PubMed]

49. Setsukinai, K.; Urano, Y.; Kakinuma, K.; Majima, H.J.; Nagano, T. Development of novel fluorescence probes that can reliably detect reactive oxygen species and distinguish specific species. J. Biol. Chem. 2003, 278, 3170-3175. [CrossRef] [PubMed]

50. Shirotani, K.; Tsubuki, S.; Iwata, N.; Takaki, Y.; Harigaya, W.; Maruyama, K.; Kiryu-Seo, S.; Kiyama, H.; Iwata, H.; Tomita, T.; et al. Neprilysin degrades both amyloid $\beta$ peptides 1-40 and 1-42 most rapidly and efficiently among thiorphan- and phosphoramidon-sensitive endopeptidases. J. Biol. Chem. 2001, 276, 21895-21901. [CrossRef] [PubMed]

51. Takaki, Y.; Iwata, N.; Tsubuki, S.; Taniguchi, S.; Toyoshima, S.; Lu, B.; Gerard, N.P.; Gerard, C.; Lee, H.J.; Shirotani, K.; et al. Biochemical identification of the neutral endopeptidase family member responsible for the catabolism of amyloid $\beta$ peptide in the brain. J. Biochem. 2000, 128, 897-902. [CrossRef] [PubMed]

52. Vekrellis, K.; Ye, Z.; Qiu, W.Q.; Walsh, D.; Hartley, D.; Chesneau, V.; Rosner, M.R.; Selkoe, D.J. Neurons regulate extracellular levels of amyloid beta-protein via proteolysis by insulin-degrading enzyme. J. Neurosci. 2000, 20, 1657-1665. [PubMed]

53. Qiu, W.Q.; Walsh, D.M.; Ye, Z.; Vekrellis, K.; Zhang, J.; Podlisny, M.B.; Rosner, M.R.; Safavi, A.; Hersh, L.B.; Selkoe, D.J. Insulin-degrading enzyme regulates extracellular levels of amyloid $\beta$-protein by degradation. J. Biol. Chem. 1998, 273, 32730-32738. [CrossRef] [PubMed]

54. Evin, G.; Weidemann, A. Biogenesis and metabolism of Alzheimer's disease A $\beta$ amyloid peptides. Peptides 2002, 23, 1285-1297. [CrossRef]

55. Rohan de Silva, H.A.; Jen, A.; Wickenden, C.; Jen, L.S.; Wilkinson, S.L.; Patel, A.J. Cell-specific expression of $\beta$-amyloid precursor protein isoform mrnas and proteins in neurons and astrocytes. Brain Res. Mol. Brain Res. 1997, 47, 147-156. [CrossRef]

56. Duering, M.; Grimm, M.O.; Grimm, H.S.; Schroder, J.; Hartmann, T. Mean age of onset in familial Alzheimer's disease is determined by amyloid $\beta 42$. Neurobiol. Aging 2005, 26, 785-788. [CrossRef] [PubMed]

57. Dyrks, T.; Dyrks, E.; Monning, U.; Urmoneit, B.; Turner, J.; Beyreuther, K. Generation of $\beta$ A4 from the amyloid protein precursor and fragments thereof. FEBS Lett. 1993, 335, 89-93. [CrossRef]

58. Selkoe, D.J.; American College of Physicians; American Physiological Society. Alzheimer disease: Mechanistic understanding predicts novel therapies. Ann. Intern. Med. 2004, 140, 627-638. [CrossRef] [PubMed]

59. Sen, C.K.; Khanna, S.; Roy, S. Tocotrienols: Vitamin E beyond tocopherols. Life Sci. 2006, 78, $2088-2098$. [CrossRef] [PubMed]

60. Rondanelli, M.; Faliva, M.A.; Peroni, G.; Moncaglieri, F.; Infantino, V.; Naso, M.; Perna, S. Focus on pivotal role of dietary intake (diet and supplement) and blood levels of tocopherols and tocotrienols in obtaining successful aging. Int. J. Mol. Sci. 2015, 16, 23227-23249. [CrossRef] [PubMed]

61. Grimm, M.O.W.; Hartmann, T. Recent understanding of the molecular mechanisms of Alzheimer's disease. J. Addict. Res. Ther. 2012, 5, 1-27. 
62. Nohturfft, A.; Yabe, D.; Goldstein, J.L.; Brown, M.S.; Espenshade, P.J. Regulated step in cholesterol feedback localized to budding of scap from er membranes. Cell 2000, 102, 315-323. [CrossRef]

63. Sakai, J.; Duncan, E.A.; Rawson, R.B.; Hua, X.; Brown, M.S.; Goldstein, J.L. Sterol-regulated release of SREBP-2 from cell membranes requires two sequential cleavages, one within a transmembrane segment. Cell 1996, 85, 1037-1046. [CrossRef]

64. Mangialasche, F.; Solomon, A.; Kareholt, I.; Hooshmand, B.; Cecchetti, R.; Fratiglioni, L.; Soininen, H.; Laatikainen, T.; Mecocci, P.; Kivipelto, M. Serum levels of vitamin E forms and risk of cognitive impairment in a finnish cohort of older adults. Exp. Gerontol. 2013, 48, 1428-1435. [CrossRef] [PubMed]

65. Mangialasche, F.; Westman, E.; Kivipelto, M.; Muehlboeck, J.S.; Cecchetti, R.; Baglioni, M.; Tarducci, R.; Gobbi, G.; Floridi, P.; Soininen, H.; et al. Classification and prediction of clinical diagnosis of Alzheimer's disease based on mri and plasma measures of $\alpha$ - $/ \gamma$-tocotrienols and $\gamma$-tocopherol. J. Intern. Med. 2013, 273, 602-621. [CrossRef] [PubMed]

66. Mangialasche, F.; Kivipelto, M.; Mecocci, P.; Rizzuto, D.; Palmer, K.; Winblad, B.; Fratiglioni, L. High plasma levels of vitamin E forms and reduced Alzheimer's disease risk in advanced age. J. Alzheimers Dis. 2010, 20, 1029-1037. [PubMed]

67. Mangialasche, F.; Xu, W.; Kivipelto, M.; Costanzi, E.; Ercolani, S.; Pigliautile, M.; Cecchetti, R.; Baglioni, M.; Simmons, A.; Soininen, H.; et al. Tocopherols and tocotrienols plasma levels are associated with cognitive impairment. Neurobiol. Aging 2012, 33, 2282-2290. [CrossRef] [PubMed]

68. Morris, M.C.; Evans, D.A.; Tangney, C.C.; Bienias, J.L.; Wilson, R.S.; Aggarwal, N.T.; Scherr, P.A. Relation of the tocopherol forms to incident Alzheimer disease and to cognitive change. Am. J. Clin. Nutr. 2005, 81, 508-514. [PubMed]

69. Gopalan, Y.; Shuaib, I.L.; Magosso, E.; Ansari, M.A.; Abu Bakar, M.R.; Wong, J.W.; Khan, N.A.; Liong, W.C.; Sundram, K.; $\mathrm{Ng}$, B.H.; et al. Clinical investigation of the protective effects of palm vitamin $\mathrm{E}$ tocotrienols on brain white matter. Stroke 2014, 45, 1422-1428. [CrossRef] [PubMed]

70. Farina, N.; Isaac, M.G.; Clark, A.R.; Rusted, J.; Tabet, N. Vitamin E for Alzheimer's dementia and mild cognitive impairment. Cochrane Database Syst. Rev. 2012, 11. [CrossRef]

71. Barnes, D.E.; Yaffe, K. Vitamin E and donepezil for the treatment of mild cognitive impairment. N. Engl. J. Med. 2005, 353, 951-952. [PubMed]

72. Usoro, O.B.; Mousa, S.A. Vitamin E forms in Alzheimer's disease: A review of controversial and clinical experiences. Crit. Rev. Food Sci. Nutr. 2010, 50, 414-419. [CrossRef] [PubMed]

73. Miller, E.R., 3rd; Pastor-Barriuso, R.; Dalal, D.; Riemersma, R.A.; Appel, L.J.; Guallar, E. Meta-analysis: High-dosage vitamin E supplementation may increase all-cause mortality. Ann. Intern. Med. 2005, 142, 37-46. [CrossRef] [PubMed]

74. Behl, C. Amyloid $\beta$-protein toxicity and oxidative stress in Alzheimer's disease. Cell Tissue Res. 1997, 290, 471-480. [CrossRef] [PubMed]

75. Nishida, Y.; Ito, S.; Ohtsuki, S.; Yamamoto, N.; Takahashi, T.; Iwata, N.; Jishage, K.; Yamada, H.; Sasaguri, H.; Yokota, S.; et al. Depletion of vitamin E increases amyloid $\beta$ accumulation by decreasing its clearances from brain and blood in a mouse model of Alzheimer disease. J. Biol. Chem. 2009, 284, 33400-33408. [CrossRef] [PubMed]

76. Sinha, M.; Bir, A.; Banerjee, A.; Bhowmick, P.; Chakrabarti, S. Multiple mechanisms of age-dependent accumulation of amyloid $\beta$ protein in rat brain: Prevention by dietary supplementation with $N$-acetylcysteine, $\alpha$-lipoic acid and $\alpha$-tocopherol. Neurochem. Int. 2016, 95, 92-99. [CrossRef] [PubMed]

77. Thakurta, I.G.; Banerjee, P.; Bagh, M.B.; Ghosh, A.; Sahoo, A.; Chattopadhyay, S.; Chakrabarti, S. Combination of $\mathrm{N}$-acetylcysteine, $\alpha$-lipoic acid and $\alpha$-tocopherol substantially prevents the brain synaptosomal alterations and memory and learning deficits of aged rats. Exp. Gerontol. 2014, 50, 19-25. [CrossRef] [PubMed]

78. Grimm, H.S.; Beher, D.; Lichtenthaler, S.F.; Shearman, M.S.; Beyreuther, K.; Hartmann, T. $\gamma$-secretase cleavage site specificity differs for intracellular and secretory amyloid $\beta$. J. Biol. Chem. 2003, 278, 13077-13085. [CrossRef] [PubMed]

79. Smith, P.K.; Krohn, R.I.; Hermanson, G.T.; Mallia, A.K.; Gartner, F.H.; Provenzano, M.D.; Fujimoto, E.K.; Goeke, N.M.; Olson, B.J.; Klenk, D.C. Measurement of protein using bicinchoninic acid. Anal. Biochem. 1985, 150, 76-85. [CrossRef] 
80. Ida, N.; Hartmann, T.; Pantel, J.; Schroder, J.; Zerfass, R.; Forstl, H.; Sandbrink, R.; Masters, C.L.; Beyreuther, K. Analysis of heterogeneous A4 peptides in human cerebrospinal fluid and blood by a newly developed sensitive western blot assay. J. Biol. Chem. 1996, 271, 22908-22914. [PubMed]

81. Grimm, M.O.; Zinser, E.G.; Grosgen, S.; Hundsdorfer, B.; Rothhaar, T.L.; Burg, V.K.; Kaestner, L.; Bayer, T.A.; Lipp, P.; Muller, U.; et al. Amyloid precursor protein (APP) mediated regulation of ganglioside homeostasis linking Alzheimer's disease pathology with ganglioside metabolism. PLoS ONE 2012, 7, e34095. [CrossRef] [PubMed]

82. Grimm, M.O.; Kuchenbecker, J.; Grosgen, S.; Burg, V.K.; Hundsdorfer, B.; Rothhaar, T.L.; Friess, P.; de Wilde, M.C.; Broersen, L.M.; Penke, B.; et al. Docosahexaenoic acid reduces amyloid $\beta$ production via multiple pleiotropic mechanisms. J. Biol. Chem. 2011, 286, 14028-14039. [CrossRef] [PubMed]

83. Grimm, M.O.; Mett, J.; Stahlmann, C.P.; Grosgen, S.; Haupenthal, V.J.; Blumel, T.; Hundsdorfer, B.; Zimmer, V.C.; Mylonas, N.T.; Tanila, H.; et al. APP intracellular domain derived from amyloidogenic $\beta$ - and $\gamma$-secretase cleavage regulates neprilysin expression. Front. Aging Neurosci. 2015, 7, 77-94. [CrossRef] [PubMed]

84. $\mathrm{Xu}, \mathrm{Z}$. Comparison of extraction methods for quantifying vitamin E from animal tissues. Bioresour. Technol. 2008, 99, 8705-8709. [CrossRef] [PubMed]

85. Lauridsen, C.; Leonard, S.W.; Griffin, D.A.; Liebler, D.C.; McClure, T.D.; Traber, M.G. Quantitative analysis by liquid chromatography-tandem mass spectrometry of deuterium-labeled and unlabeled vitamin $\mathrm{E}$ in biological samples. Anal. Biochem. 2001, 289, 89-95. [CrossRef] [PubMed]

(C) 2016 by the authors; licensee MDPI, Basel, Switzerland. This article is an open access article distributed under the terms and conditions of the Creative Commons Attribution (CC-BY) license (http://creativecommons.org/licenses/by/4.0/). 